\title{
Future rainfall variations reduce abundances of aboveground arthropods in model agroecosystems with different soil types
}

\section{Johann G. Zaller ${ }^{1 *}$, Laura Simmer ${ }^{1}$, Nadja Santer ${ }^{1}$, James Tabi Tataw ${ }^{1}$, Herbert Formayer ${ }^{2}$, Erwin Murer ${ }^{3}$, Johannes Hösch ${ }^{4}$ and Andreas Baumgarten ${ }^{4}$}

\footnotetext{
${ }^{1}$ Department of Integrative Biology and Biodiversity Research, Institute of Zoology, University of Natural Resources and Life Sciences Vienna, Austria

${ }^{2}$ Department of Water-Atmosphere-Environment, Institute of Meteorology, University of Natural Resources and Life Sciences Vienna, Austria

${ }^{3}$ Institute of Land and Water Management Research, Federal Agency for Water Management, Petzenkirchen, Austria

${ }^{4}$ Division for Food Security, Institute of Soil Health and Plant Nutrition, Austrian Agency for Health and Food Safety (AGES), Vienna, Austria
}

\section{Edited by:}

Vimala Nair, University of Florida,

USA

\section{Reviewed by:}

Astrid Rita Taylor, Swedish

University of Agricultural Sciences,

Sweden

Holger Hoffmann, Leibniz

Universität Hannover, Germany

Todd Z. Osborne, University of

Florida, USA

\section{*Correspondence:}

Johann G. Zaller, Department of Integrative Biology and Biodiversity Research, Institute of Zoology,

University of Natural Resources and

Life Sciences Vienna, Gregor

Mendel Straße 33, A-1180 Vienna,

Austria

e-mail: johann.zaller@boku.ac.at
Climate change scenarios for Central Europe predict less frequent but heavier rainfalls and longer drought periods during the growing season. This is expected to alter arthropods in agroecosystems that are important as biocontrol agents, herbivores or food for predators (e.g., farmland birds). In a lysimeter facility (totally 183 - $\mathrm{m}^{2}$-plots), we experimentally tested the effects of long-term current vs. prognosticated future rainfall variations $115 \%$ increased rainfall per event, $25 \%$ more dry days) according to regionalized climate change models from the Intergovernmental Panel on Climate Change (IPCC) on aboveground arthropods in winter wheat (Triticum aestivum L.) cultivated at three different soil types (calcaric phaeozem, calcic chernozem and gleyic phaeozem). Soil types were established 17 years and rainfall treatments 1 month before arthropod sampling; treatments were fully crossed and replicated three times. Aboveground arthropods were assessed by suction sampling, their mean abundances $( \pm$ SD) differed between April, May and June with $20 \pm 3 \mathrm{~m}^{-2}, 90 \pm 35 \mathrm{~m}^{-2}$, and $289 \pm 93$ individuals $\mathrm{m}^{-2}$, respectively. Averaged across sampling dates, future rainfall reduced the abundance of spiders (Araneae, $-47 \%$ ), cicadas and leafhoppers (Auchenorrhyncha, $-39 \%$ ), beetles (Coleoptera, $-52 \%$ ), ground beetles (Carabidae, $-41 \%$ ), leaf beetles (Chrysomelidae, $-64 \%$ ), spring tails (Collembola, $-58 \%$ ), flies (Diptera, $-73 \%$ ) and lacewings (Neuroptera, $-73 \%$ ) but increased the abundance of snails (Gastropoda, $+69 \%$ ). Across sampling dates, soil types had no effects on arthropod abundances. Arthropod diversity was neither affected by rainfall nor soil types. Arthropod abundance was positively correlated with weed biomass for almost all taxa; abundance of Hemiptera and of total arthropods was positively correlated with weed density. These detrimental effects of future rainfall variations on arthropod taxa in wheat fields can potentially alter arthropod-related agroecosystem services.

Keywords: agroecology, climate change ecology, precipitation patterns, soil types, aboveground invertebrates, lysimeter, winter wheat, animal-plant interactions

\section{INTRODUCTION}

Climate change will very likely cause a seasonal shift in precipitation in Central Europe resulting in less frequent but more extreme rainfall events during summer but increased precipitation during winter (IPCC, 2007, 2013). Regionalisations of these climate models for eastern parts of Central Europe prognosticate little changes or even slight decreases in annual rainfall amounts until 2100 (Eitzinger et al., 2001; Kromp-Kolb et al., 2008). Indeed, so far for eastern Austria no change in total yearly precipitation was measured during the last decades (Formayer and Kromp-Kolb, 2009). The direction, magnitude and variability of such changes in precipitation events and their effects on ecosystem functioning will depend on how much the change deviates from the existing variability and the ability of ecosystems and inhabiting organisms to adapt to the new conditions (Beier et al., 2012).
In many natural and agriculturally managed ecosystems arthropods are the most abundant and diverse group of animals (Altieri, 1999; Speight et al., 2008). Abundances of epigeic arthropods in an arable field can reach thousands of individuals $\mathrm{m}^{-2}$ comprising hundreds of species (Romanowsky and Tobias, 1999; Östman et al., 2001; Pfiffner and Luka, 2003; Batary et al., 2012; Frank et al., 2012; Querner et al., 2013). These arthropods play important ecological roles as herbivores and detritivores (Seastedt and Crossley, 1984), are valued for pollination, seed dispersal and predation (Steffan-Dewenter et al., 2001), are important predators and parasitoids (Thies et al., 2003; Drapela et al., 2008; Zaller et al., 2008a, 2009) and are a food source for many vertebrates and invertebrates (Price, 1997; Brantley and Ford, 2012; Hallmann et al., 2014). As arthropods can have a strong influence on nutrient cycling processes (Seastedt and Crossley, 1984), they are also 
very important for ecosystem net primary production (Abbas and Parwez, 2012). Predicted longer drought intervals between rainfall events will increase drought stress for crops while changes in the amount and timing of rainfall will affect yields and the biomass production of crops (Eitzinger et al., 2001; Alexandrov et al., 2002; Thaler et al., 2008). These changes in vegetation structure and quality will also affect associated arthropods (Andow, 1991). Moreover, it has also been shown that changes in the magnitude and variability of rainfall events is likely to be more important for arthropods than changes in annual amounts of rainfall (Curry, 1994; Speight et al., 2008; Singer and Parmesan, 2010). Most studies investigating potential effects of climate change on arthropods have focused on the effects of changes in atmospheric $\mathrm{CO}_{2}$ concentrations or temperature rather than precipitation (e.g., Cannon, 1998; Andrew and Hughes, 2004; Hegland et al., 2009; Hamilton et al., 2012). However, changes in variations of rainfall are likely to have a greater effect on species' distributions than are changes in temperature, especially among rare species (Elmes and Free, 1994).

Surprisingly, very few studies investigated the effects of different rainfall variations on aboveground arthropod abundance in arable agroecosystems, although arable land is ecologically important in terms of its diverse arthropod fauna (Frampton et al., 2000; Tscharntke et al., 2005; Drapela et al., 2008) and its interaction with natural ecosystems in a landscape matrix (Tscharntke and Brandl, 2004; Frank et al., 2012; Balmer et al., 2013; Coudrain et al., 2014). Results from studies investigating the effects of rainfall variations on arthropods are not consistent ranging from increased spider activity to a reduced activity of Collembola under reduced rainfall (Lensing et al., 2005) while others showed little influence of rainfall on spiders (Buchholz, 2010). It also appears that even short rainfall events in spring can influence various groups of farmland arthropods for the following months (Frampton et al., 2000).

To the best of our knowledge, no study assessed the effects of rainfall variations on arthropods in wheat, one of the most important cereal crops worldwide. Moreover, experiments studying the effects of precipitation on ecosystems are usually conducted at different locations with different soil types, thus confounding location with soil types and making it impossible to test to what extent soil types can potentially buffer rainfall variations on ecosystem processes (Beier et al., 2012). The few studies investigating arthropod abundance in different soil types found a significant difference in soil fauna abundance and diversity (Loranger-Merciris et al., 2007) or invertebrate community composition between different soil types (Ivask et al., 2008; Tabi Tataw et al., 2014).

Hence, the objectives of the current study were: (1) To examine effects of different rainfall variations on the abundance of aboveground arthropods in winter wheat, (2) to assess to what extent different soil types alter potential responses of aboveground arthropods to rainfall variations. The investigations were based on the hypotheses that differences in the amount and variability of rainfall alter the structure of winter wheat stands by either affecting growth of crops and/or weeds (Porter and Semenov, 2005) and consequently affecting the abundance and diversity of arthropods (Duelli and Obrist, 2003; Menalled et al., 2007). As the composition of arthropod communities changes during the season we expected that different arthropod taxa would be differently affected by rainfall variations (Price et al., 2011). Moreover, different moisture sensitivities/drought tolerances of arthropod taxa (Finch et al., 2008) will be affected by soil types with different water holding capacities and soil types will also modify the growth and structure of vegetation that will interact with rainfall variations in affecting arthropods.

\section{MATERIALS AND METHODS STUDY SITE}

The experiment was carried out in the lysimeter experimental facility of the Austrian Agency for Health and Food Safety (AGES), in Vienna, Austria (northern latitude $48^{\circ} 15^{\prime} 11^{\prime \prime}$, eastern longitude $16^{\circ} 28^{\prime} 47^{\prime \prime}$ ) at an altitude of $160 \mathrm{~m}$ above sea level. The facility is located in a transition area of the Western European oceanic (mild winters, wet, cool summer) and the Eastern European continental climatic area (cold winters, hot summers) ecologically referred to as the Pannonium region. Long-term mean annual precipitation at this site is $550-600 \mathrm{~mm}$ at a mean air temperature of $9.5^{\circ} \mathrm{C}$ (Danneberg et al., 2001).

The lysimeter facility was established in 1995 and consists of 18 cylindrical vessels made of stainless steel each with a surface area of $3.02 \mathrm{~m}^{2}$ and a depth of $2.45 \mathrm{~m}$ (Figure 1). The lysimeters are arranged in two parallel rows with nine lysimeter plots in each row; one row was subjected to current rainfall the other row to prognosticated rainfall. Within each row three soil types were randomized to ensure replicates of each soil type in each row (see below for more details on treatment factors); each treatment was replicated three times $(n=3)$.

\section{EXPERIMENTAL TREATMENTS \\ SOIL TYPES}

In 1995, the lysimeters were filled with three different soil types representing around $80 \%$ of the agriculturally most productive

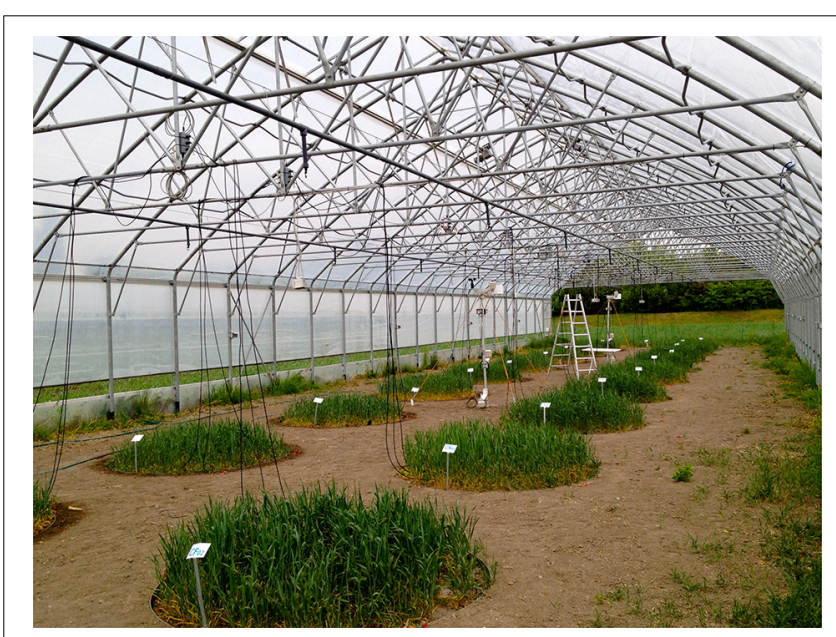

FIGURE 1 | Experimental winter wheat plots containing three different soil types (calcaric phaeozem, calcic chernozem, gleyic phaeozem) subjected to long-time current prognosticated rainfall variations according to regionalized climate change models. 
area in Austria (region Marchfeld; east of Vienna, Austria): calcaric phaeozem (S), calcic chernozem (T), and gleyic phaeozem (F; soil nomenclature after World Soil Classification, FAO, 2002). The soil material was carefully excavated from their native sites in $10 \mathrm{~cm}$ layers and filled into the lysimeter vessels retaining their original bulk densities of $1.4 \mathrm{~g} \mathrm{~cm}^{-3}$ (Danneberg et al., 2001). See Tabi Tataw et al. (2014) for further details on the soil characteristics. Briefly, the calcic chernozem and the calcaric phaeozem have a fully developed AC-profile, emerging from carbonate-fine siliceous material. The thickness of the A horizon is at least $30 \mathrm{~cm}$, the humus form is mull with both $4.9 \%$ humus content (Nestroy et al., 2011). The calcic chernozem is moderately dry, the calcaric phaeozem is dry; both soil types consist of fine sediment to silt fine sand (Danneberg et al., 2001). The gleyic phaeozem is a soil of former hydromorphic sites with $2.1 \%$ humus content as mull; the fully developed AC-profile and the thickness of the A-horizon is at least $30 \mathrm{~cm}$ thick (Nestroy et al., 2011). This gleyic phaeozem is well supplied with water and consists of fine sediment to silt fine sand; its high lime content, gives this soil type neutral to slightly alkaline $\mathrm{pH}$. Mean profile water contents are 375, 595, and $550 \mathrm{~mm}$ for $\mathrm{S}, \mathrm{T}$, and F soil, respectively.

\section{RAINFALL SCENARIOS}

Starting in 2011, the lysimeters were subjected to two rainfall regimes, one based on past local observations ("curr. rainfall") and one based on a regionalization of the IPCC 2007 climate change scenario A2 for the period 2071-2100 ("progn. rainfall"; IPCC, 2007). Both the current and the future precipitation variations were calculated using the software LARS-WG (Version 3.0; Semenov and Barrow, 2002). In contrast to classic approaches using directly the projected climate time series as model input our approach with LARS-WG used only the delta values (Hoffmann and Rath, 2012, 2013). The current longterm rainfall variations was based on the precipitation amount and frequency for a location in about $10 \mathrm{~km}$ distance from the study site (village of Großenzersdorf) between the years 19712000. The future rainfall scenario for the year 2071-2100 is based on the local climatology and the climate change signal from the mean of the regional climate model scenarios from the EU-project ENSEMBLES (Christensen and Christensen, 2007). This stochastic weather generator LARS-WG was used to transfer the derived local climate change signals to daily precipitation rates. To exclude natural rainfall the lysimeters were covered with a $5 \mathrm{~m}$ high roof of transparent plastic foil from March until December in each year, all sidewalls were open allowing ventilation and free movement of animals (Figure 1). During winter the facility was uncovered and all lysimeters received natural precipitation. Rainfall amounts (tap water) according to the model calculations were applied to nine lysimeters in a row using an automatic sprinkler system. Rainfall treatments started on 22 March 2012. Until the last arthropod sampling on 18 June 2012 the curr. rainfall plots received $156.4 \mathrm{~mm}$ and the progn. rainfall plots $136.3 \mathrm{~mm}$ irrigation water $(-13 \%$ less amount of rain). Averaged over the study period, the curr. rainfall plots received $3.7 \mathrm{~mm}$ per rain event vs. $3.2 \mathrm{~mm}$ per event for the progn. rainfall plots (13\% difference); progn. rainfall had 25\% more dry days than curr. rainfall treatments (Figure 2A). Irrigation

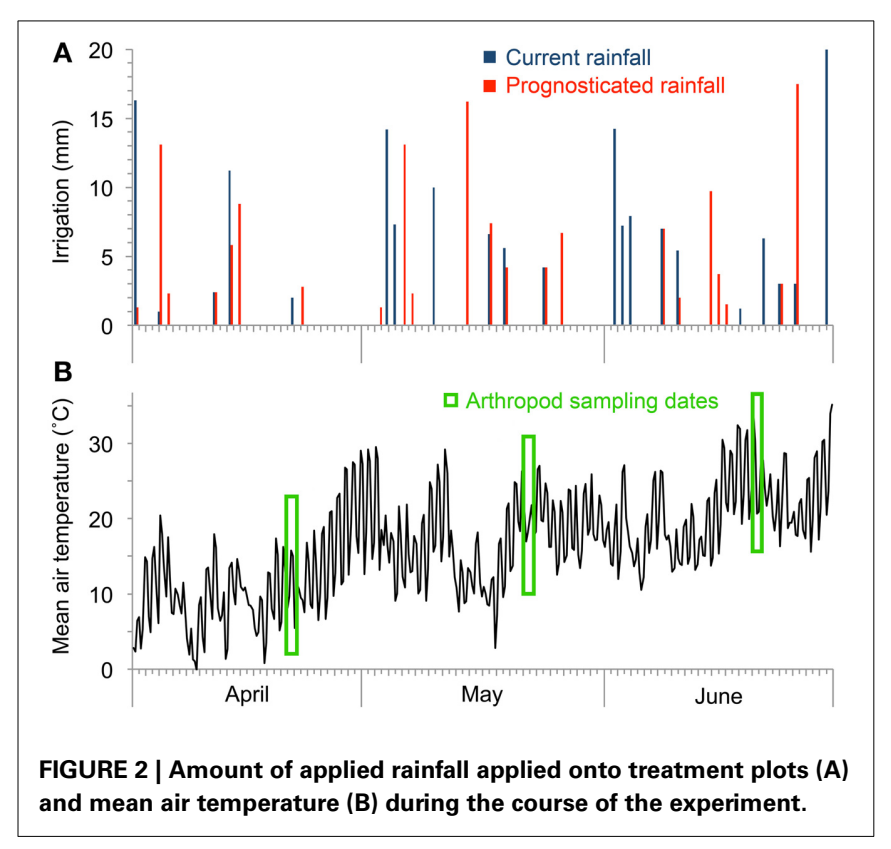

was always performed in early morning at low sunlight; side walls of the transparent cover were automatically closed during irrigation. Weather stations (Delta-T Devices, Cambridge, UK) were installed between and outside of the lysimeters for monitoring air temperature (Figure 2B), wind speed and direction, global radiation and rainfall. Soil matric potential $(\psi \mathrm{m}$, also called soil water potential) was measured using three $\mathrm{pF}$ sensors per lysimeter installed in $10 \mathrm{~cm}$ depth (ecoTech UmweltMesssysteme GmbH, Bonn, Germany). The soil matric potential was automatically measured every $15 \mathrm{~min}$ and represents the pressure it takes to pull water out of soil and increases as the soil gets drier. Technically the $\mathrm{pF}$ sensor measure heat capacity in a porous ceramic tip that contains a heating element and temperature sensors. The correlations of $\mathrm{pF}$ values and measured heat capacity is achieved by a sensor-specific calibration curve (www. ecotech-bonn.de/en/produkte/Bodenkunde/pF-meter.html). The matric potential changes with the soil water content and commonly varies between different soil types. Soil matric potential is usually expressed in $\mathrm{pF}$ units which is the log of the soil tension in $\mathrm{hPa}$ (e.g., $\log$ of $10,000 \mathrm{hPa}$ is equal to $p F=4$ ). Daily $\mathrm{pF}$ values were calculated by averaging the individual readings of each lysimeter. Field capacity of soil types was $p F=1.8$, permanent wilting point for crops $p F=4.2$.

\section{CROP WHEAT}

Winter wheat (Triticum aestivum L. cv. Capo) was sown at a density of 400 seeds $\mathrm{m}^{-2}$ on 11 October 2011 after the precrop white mustard. Weeds in the treatment plots were controlled by spraying a mixture of the herbicides Express-SW (active ingredient: tribenuronmethyl; Kwizda Agro, Vienna, Austria) at $25 \mathrm{~g} \mathrm{ha}^{-1}$, Starane XL (a.i.: fluroxypyr and florasulam; Dow AgroSciences, Indianapolis, IN, USA) at $750 \mathrm{ml} \mathrm{ha}^{-1}$ and water at $300 \mathrm{l} \mathrm{ha}^{-1}$ on 30 March 2012. Fertilization was applied according to recommendations for farmers after soil analyses (Table 1). 
Table 1 | Fertilization of winter wheat crops in lysimeter plots with different soil types (S - calcaric phaeozem, F-gleyic phaeozem, T-calcic chernozem).

\begin{tabular}{lcccl}
\hline Fertilizer type & \multicolumn{2}{c}{$\begin{array}{c}\text { Fertilizer amount } \\
\text { per soil type } \\
\text { (kg ha-1) }\end{array}$} & Date \\
\cline { 2 - 4 } & $\boldsymbol{S}$ & $\boldsymbol{F}$ & $\boldsymbol{T}$ & \\
\hline $\mathrm{P}_{2} \mathrm{O}_{5}$-Triplesuperphosphate & 0 & 55 & 55 & 11 October 2011 \\
$\mathrm{K}_{2} \mathrm{O}-\mathrm{K}$-Kali 60 & 40 & 0 & 0 & 11 October 2011 \\
N-NAC (Nitramoncal 27\%) & 25 & 40 & 40 & 08 March 2012 \\
N-NAC (Nitramoncal 27\%) & 30 & 40 & 40 & 12 April 2012 \\
N-NAC (Nitramoncal 27\%) & 35 & 50 & 50 & 16 May 2012 \\
\hline
\end{tabular}

Wheat growth was measured from the soil surface to the tip of the spike on 10-15 marked crop plants per lysimeter around the arthropod sampling dates (see below). Additionally, the number of weed individuals per lysimeter (weed density) was counted during these dates. Lysimeters were harvested on 5 July 2012 by cutting all vegetation (winter wheat and weeds) by hand at $5 \mathrm{~cm}$ above surface. Crop and weed plants were separated, crop plants devided in straw and spikes and everything was weighed after drying at $50^{\circ} \mathrm{C}$ for $48 \mathrm{~h}$. In order to avoid boundary effects all measurements on crops were conducted in the central area of each lysimeter up to $20 \mathrm{~cm}$ distance from the edge of each lysimeter.

\section{ARTHROPOD SAMPLING}

All arthropods dwelling on the soil surface and on the vegetation in each of the 18 lysimeters were collected using a commercial garden vacuum (Stihl SH 56-D, Dieburg, Germany) equipped with an insect sampling net. For sampling, the suction tube was carefully moved between the crop plants across the lysimeter area in order to avoid that the sampling efficiency is too much influenced by vegetation structure, height and density (Southwood, 1978; Brook et al., 2008). To impede the escape of the arthropods, a $1 \mathrm{~m}$ high barrier made of plastic film was attached to the borders of the lysimeter vessels. Suction sampling was performed for $5 \mathrm{~min}$ in each lysimeter; afterwards, each plot was thoroughly inspected for another $20 \mathrm{~min}$ for remaining arthropods. This sampling procedure was performed on April 24-25, May 22-23, and June 19, 2012. Air temperature during arthropod sampling dates was on average $18.2^{\circ} \mathrm{C}$ on the first sampling event, $23.3^{\circ} \mathrm{C}$ on the second, and $30.4^{\circ} \mathrm{C}$ on the third sampling event (Figure 2B). Sampling was carried out only when the vegetation and soil surface was dry. After collection, the arthropods were sorted out, cleaned from attached soil, preserved in $80 \%$ ethylene alcohol and identified at the level of taxonomic order or families (Bellmann, 1999; Bährmann and Müller, 2005). Taxa with less than 0.3 individuals $\mathrm{m}^{-2}$ were lumped together in a group of rare individuals. Arthropod abundance was expressed in individuals $\mathrm{m}^{-2}$ and relative abundance of the identified groups to the arthropod community present in each lysimeter was calculated in percentage based on the $\mathrm{m}^{-2}$ values.

\section{STATISTICAL ANALYSES}

First, all measured parameters were tested for normal distribution and variance homogeneity using the Kolmogorov-Smirnov-Test and Levene-Test, respectively. The two parameters that did not meet the requirements of parametric statistics, Hemiptera and total individuals from the May sampling, were Boxcox transformed. Secondly, for all arthropod abundance parameters, repeated measurement analysis of variance (ANOVA) with the factors Rainfall (two levels: longtime current rainfall variations vs. prognosticated rainfall variations), Soil type (three levels: F, S, and T soils) and Sampling date (three dates: April, May, June sampling) were conducted. Additionally, to test for treatment effects at each sampling date separately, two-factorial ANOVAs with the factors Rainfall and Soil type and their interactions were conducted for arthropod taxa and for soil $\mathrm{pF}$ values. As a measure of community diversity the Simpson and the Shannon index were calculated and also tested with a two-factorial ANOVA for each sampling date separately (Rosenzweig, 1995). Pearson correlations were performed between arthropod abundance, crop height, crop and weed biomass and weed abundance. All statistical analyses were performed using the freely available software "R" (version 3.0.2; R Core Team, 2013). Statistical results with $P>0.50<0.10$ were considered marginally significant. Values within the text are means \pm SD.

\section{RESULTS}

Soil matrix potential was significantly affected by rainfall $(P<$ $0.001)$ and soil types $(P<0.001$; rainfall $\times$ soil type interaction: $P<0.001)$ with sandy soils showing the lowest and $\mathrm{F}$ and $\mathrm{T}$ soil the highest $\mathrm{pF}$ values under both rainfall treatments (Figure 3 ).

Arthropod abundances differed highly significantly between sampling dates; rainfall variations significantly affected arthropod abundances at different sampling dates (i.e., rainfall $\times$ sampling date interaction; repeated measures ANOVA, Table 2, Figure 4). Averaged across rainfall variations and soil types total arthropod abundance in April was $20.38 \pm 3.24 \mathrm{~m}^{-2}$, in May $89.62 \pm$ $34.74 \mathrm{~m}^{-2}$ and in June $289.23 \pm 92.84 \mathrm{~m}^{-2}$ (Figure 4). Overall, Hymenoptera was the dominant order in April; Hemiptera, Hymenoptera and Acari were dominant in May and Hemiptera were the most dominant group in June; especially the abundance of Hemiptera, Collembola and Acari increased from April to June.

When analyzing the arthropod abundances separately for each sampling date using Two-Way ANOVAs, prognosticated rainfall in April significantly reduced abundances of Gastropoda by $69 \%$ and of Auchenorrhyncha by 61\% (Table 3, Figure 4). In May, prognosticated rainfall significantly reduced Collembola by $53 \%$, Diptera by $59 \%$, Neuroptera by $73 \%$, and Saltatoria by $70 \%$ (Table 3, Figure 4). In April and May, soil types had no effect of the abundance of arthropods (except for the group of not determinable arthropods; Table 3). In June, prognosticated rainfall significantly reduced Araneae by $56 \%$, Auchenorrhyncha by $47 \%$, Coleoptera, and Collembola each by $62 \%$, Chrysomelidae by $66 \%$, Diptera by $77 \%$, and total individuals by $61 \%$ (Table 3 , Figure 4). All other arthropod taxa were not affected by rainfall. In June, soil types had no effect on arthropod abundance except for Auchenorrhyncha (Table 3). 

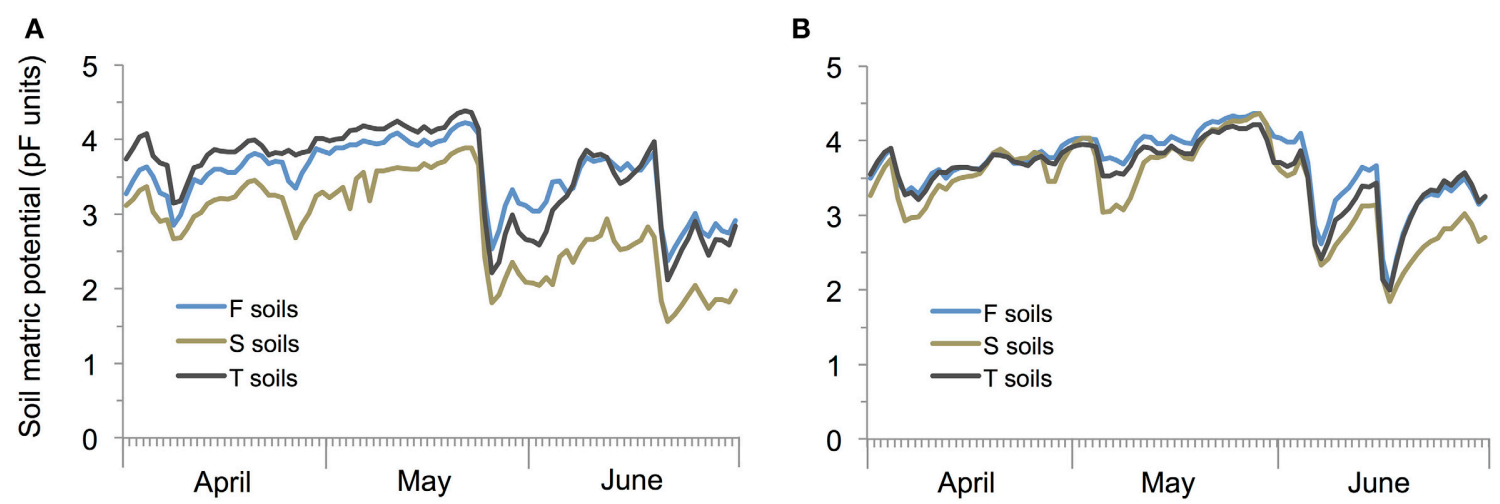

FIGURE 3 | Mean soil matric potential in pF units in winter wheat cultivated under current (A) and prognosticated rainfall variations (B) at the different soil types calcaric phaeozem (S), gleyic phaeozem (F) and calcic chernozem (T).

Table 2 | Summary of repeated measurement ANOVA results of the influence of rainfall patterns (current and prognosticated rainfall), soil types (calcaric phaeozem, calcic chernozem, and gleyic phaeozem) and sampling date (April, May, June 2012) on total abundance of arthropods in winter wheat.

\begin{tabular}{lrr}
\hline Factor & $\boldsymbol{F}$ & $\boldsymbol{P}$ \\
\hline Rainfall & 4.36 & 0.059 \\
Soil type & 0.04 & 0.961 \\
Sampling date & 20.87 & $<\mathbf{0 . 0 0 1}$ \\
Rainfall $\times$ Soil type & 1.00 & 0.398 \\
Rainfall $\times$ Sampling date & 6.33 & $\mathbf{0 . 0 0 6}$ \\
Soil type $\times$ Sampling date & 0.39 & 0.815 \\
Rainfall $\times$ Soil type $\times$ Sampling date & 0.44 & 0.776
\end{tabular}

Significant effects are in bold.

Considering the relative abundance (i.e., percentage contribution to arthropod community) of the identified arthropod groups for each sampling date, rainfall variations significantly affected Collembola $(P=0.036)$ and Neuroptera $(P=0.041)$ in May and Diptera $(P=0.041)$ in June; with the exception of the relative abundance of rare individuals in April $(P=0.027)$ the composition of arthropod communities was not affected by soil types (Figure 4).

Across sampling dates, absolute abundance of Araneae $(-43 \%)$, Coleoptera (-48\%), Carabidae $(-41 \%)$, Chrysomelidae $(-64 \%)$, Collembola $(-58 \%)$, Diptera $(-75 \%)$, Auchenorrhyncha (-39\%), and Neuroptera (-73\%) were significantly reduced under prognosticated rainfall, also total arthropod abundance were marginally significantly lower under prognosticated rainfall than under current rainfall (Table 3, Figure 5). Only the abundance of Gastropoda increased by $69 \%$ in the prognosticated rainfall compared to current rainfall (Figure 6). There was no effect of soil types on any of the identified arthropod groups across sampling dates (Table 3, Figure 6). Considering the relative abundances across sampling dates, only the relative abundance of Diptera $(P=0.027)$ and Gastropoda $(P=0.031)$ were significantly affected by rainfall; soil types only

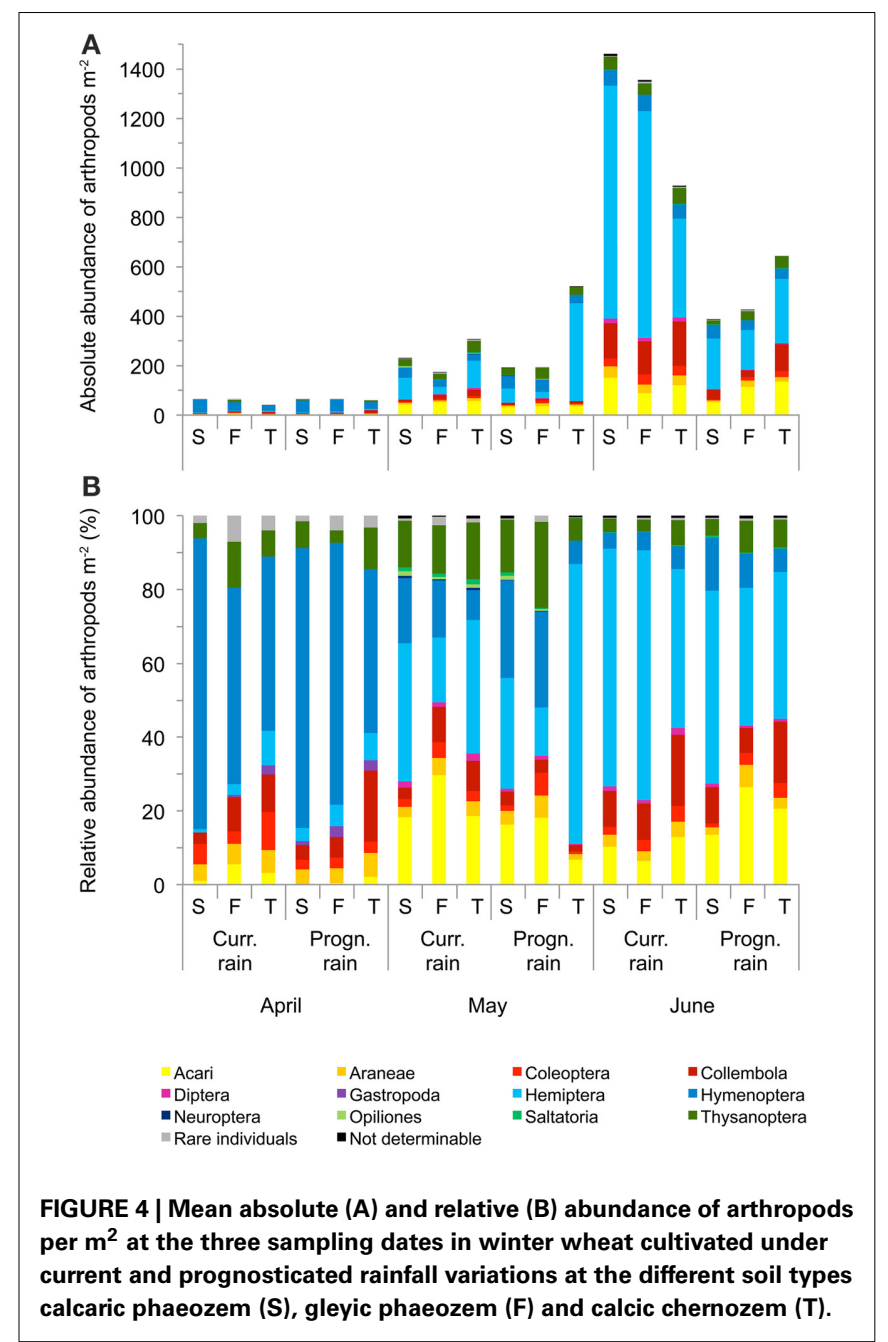

significantly affected the relative abundance of rare individuals $(P=0.010)$. Hemiptera showed the highest relative abundance in all fields (Figure 6). Rainfall variations and soil types had no effect on the diversity indices of arthropod communities (data not shown). 


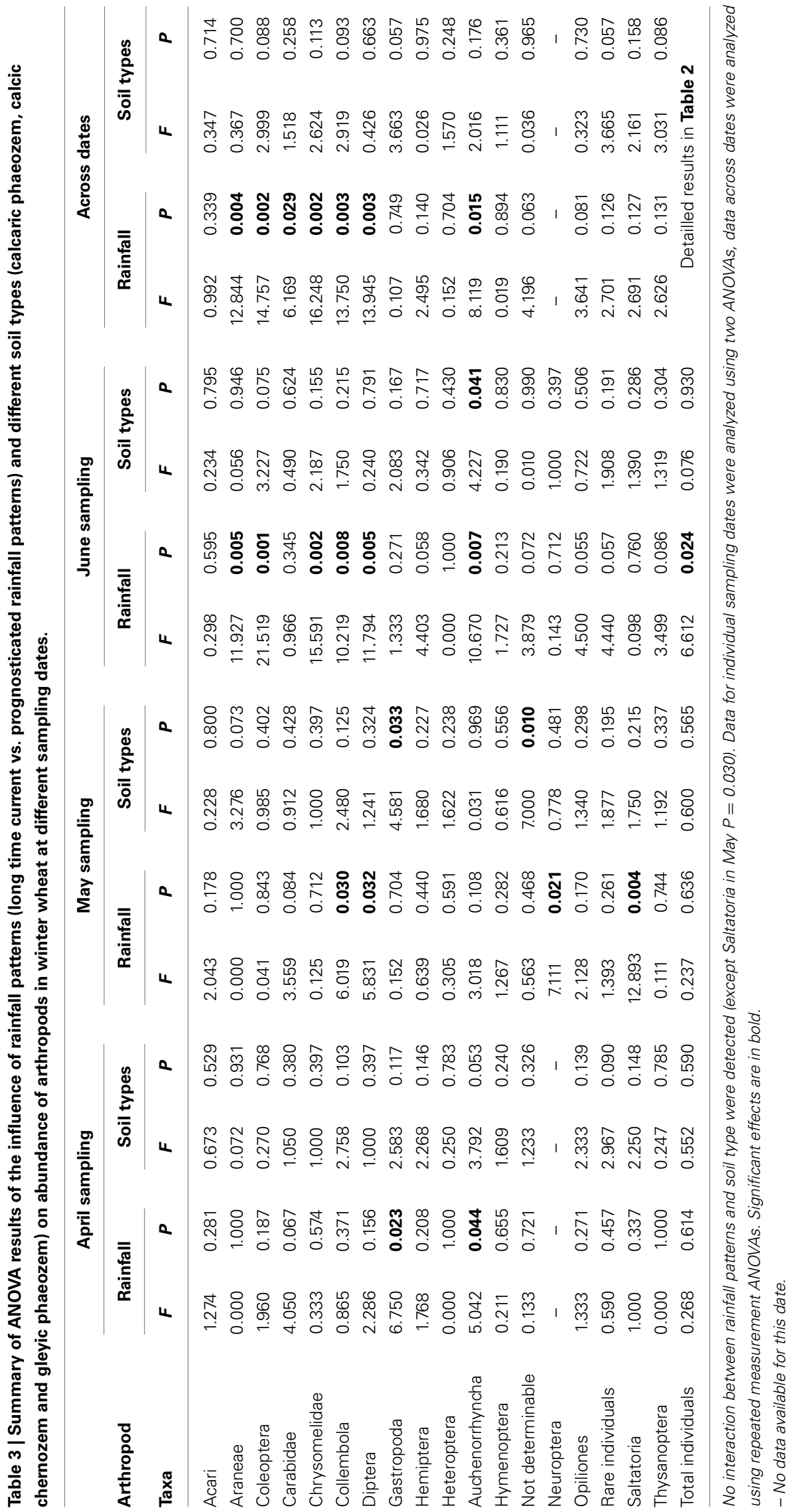




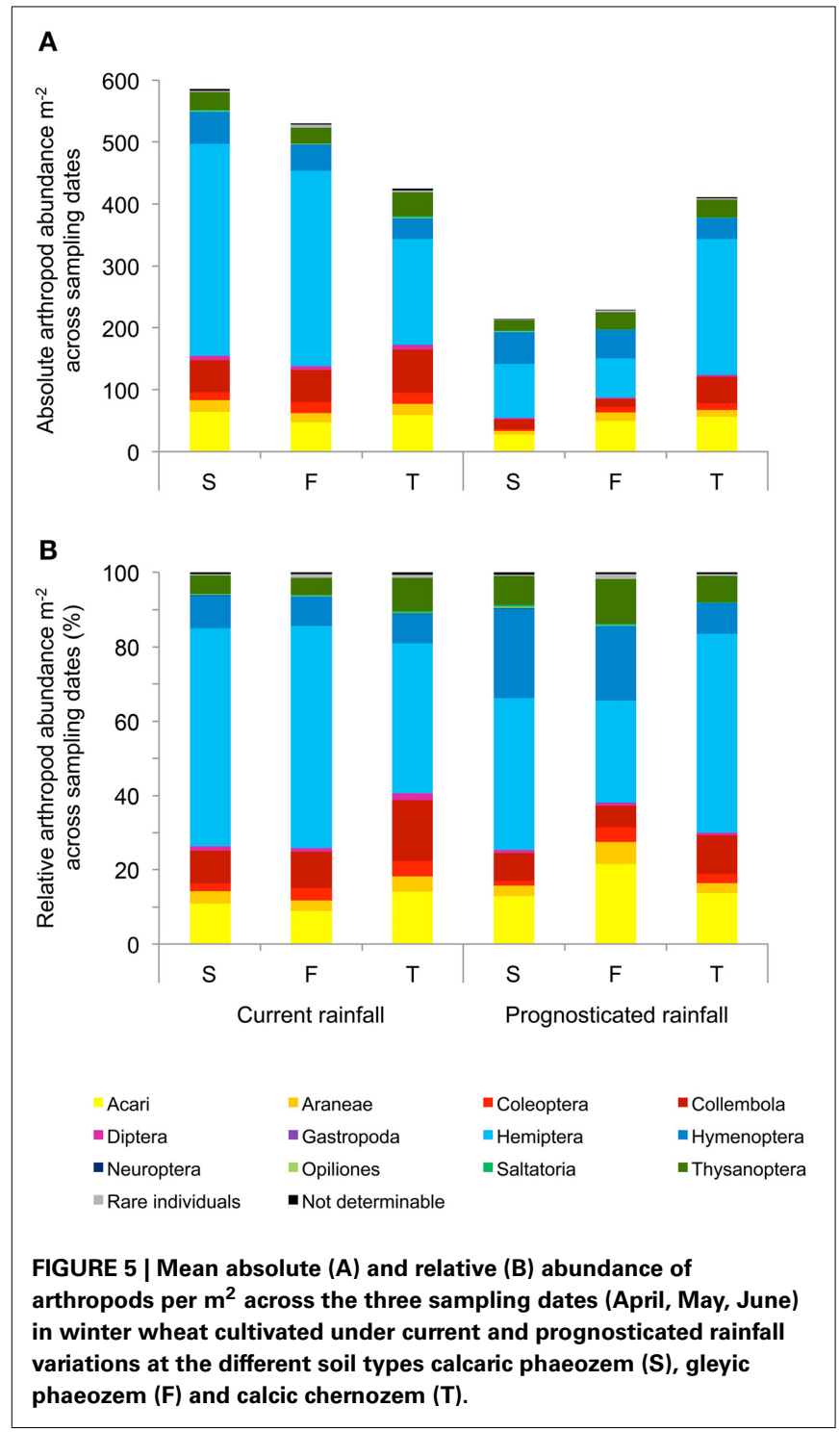

Wheat height was across sampling dates not affected by rainfall but significantly affected by soil types with lowest heights in the S soils and similarly high wheat plants in F and $\mathrm{T}$ soils (significant rainfall $\times$ soil type interaction; Table 4 ). Wheat straw biomass across sampling dates was significantly affected by rainfall and soil types (significant rainfall $\times$ soil type interaction; Table 4). Weed abundance across sampling dates was marginally significantly affected by rainfall variations and highly significantly affected by soil types (no rainfall $\times$ soil types interaction; Table 4). Weed biomass across sampling dates was only significantly affected by soil types with lowest weed biomass values in $\mathrm{F}$ soils and highest weed biomass in $\mathrm{S}$ soils (Table 4). Arthropod abundance was unrelated to winter wheat straw biomass (Table 5) wheat height or weed abundance (data not shown). However, abundances of Acari, Araneae, Collembola, Diptera, the group of not determinable arthropods and Thysanoptera was positively correlated with weed biomass (Table 5).

\section{DISCUSSION}

Results of this study show substantial reductions in the abundances of various arthropod groups but no changes on the diversity of arthropod communities under rainfall variations prognosticated for the years 2071-2100. Given the average 45\% reduction of total arthropod abundance under prognosticated rainfall means that instead of $86 \mathrm{~m}^{-2}$ only $48 \mathrm{~m}^{-2}$ arthropod individuals would be inhabiting these wheat agroecosystems. Arthropod abundance data from the current study fit well with those from a conventional cereal field in Denmark also assessed with suction sampling in late June over 2 years (Reddersen, 1997): Araneae (5.4-17.8 $\left.\mathrm{m}^{-2}\right)$, Collembola (0.65-155.9), Hemiptera (14.1-2146 $\left.\mathrm{m}^{-2}\right)$, Hymenoptera (13.5-23.9 $\left.\mathrm{m}^{-2}\right)$, however much more Coleoptera $\left(51.5-110.4 \mathrm{~m}^{-2}\right)$, Diptera $\left(66.3-104.1 \mathrm{~m}^{-2}\right)$, and Lepidoptera $\left(0.43 \mathrm{~m}^{-2}\right)$ were reported. Similar to our study, Moreby and Sotherton (1997) also found low abundances of Diptera $\left(5.4 \mathrm{~m}^{-2}\right)$, Carabidae $\left(0.82 \mathrm{~m}^{-2}\right)$, and Chrysomelidae $\left(1.36 \mathrm{~m}^{-2}\right)$ in conventional winter wheat fields in southern England with suction samplings in June and July. Reasons for differences in arthropod abundances in different studies reflect climatic differences, effects of surrounding landscape structure, influence of different insecticide usage or differences in wheat varieties. The finding that mainly abundances but not diversity was reduced suggests that the size of arthropod populations seem to be the sensitive parameter responding to rainfall variations. Whether effects of rainfall variations on arthropod abundances have consequences on how fast arthropod populations can react to environmental changes remains to be investigated by a specific experiment. We also found great differences in arthropod abundances between sampling dates from April to June reflecting the natural fluctuations due to different seasonal development of the various arthropod taxa (Frampton et al., 2000; Afonina et al., 2001; Abbas and Parwez, 2012).

\section{ARTHROPOD ABUNDANCES AS INFLUENCED BY RAINFALL}

Predicted rainfall variations reduced arthropod abundances mainly in June but had little influence in April and May. We explain this by the fact that rainfall treatments were established only 1 month before the first arthropod sampling and by the relatively small difference between the rainfall scenarios in April and May that may have been insufficient to cause shifts in arthropod abundance. Moreover, until the first arthropod sampling in April the prognosticated rainfall plots $(38 \mathrm{~mm})$ received even more rainfall than the current rainfall plots (33 $\mathrm{mm}$ rainfall). Until the second sampling date in May the current rainfall plots received $91 \mathrm{~mm}$ and the prognosticated rainfall plots $81 \mathrm{~mm}$. Even, until the June sampling the difference between the two rainfall treatments was only $20 \mathrm{~mm}$, however rainfall amount combined with extended dry periods was obviously enough to lead to several significant differences in arthropod abundances. Moreover, the increased soil matric potential in the prognosticated rainfall plots showed that soil water was less available than under the current rainfall treatment affecting wheat biomass production and weed abundance. Further, rainfall showed different effects on the availability of water in different soil types as indicated by a significant interaction between rainfall and soil types for soil matric potential. 

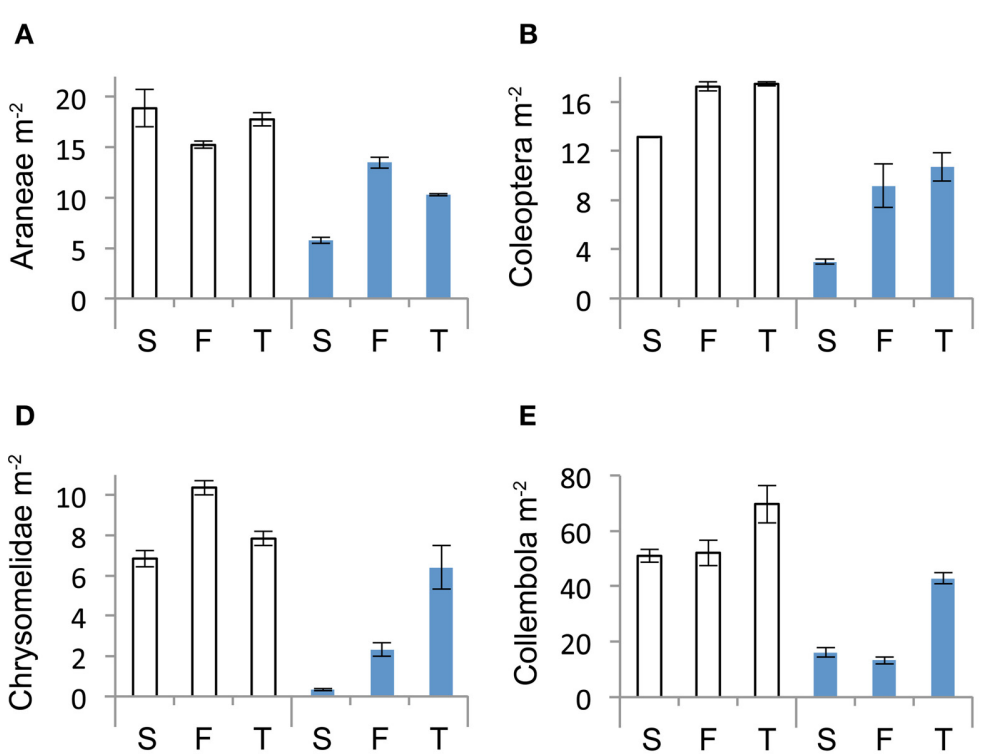

E
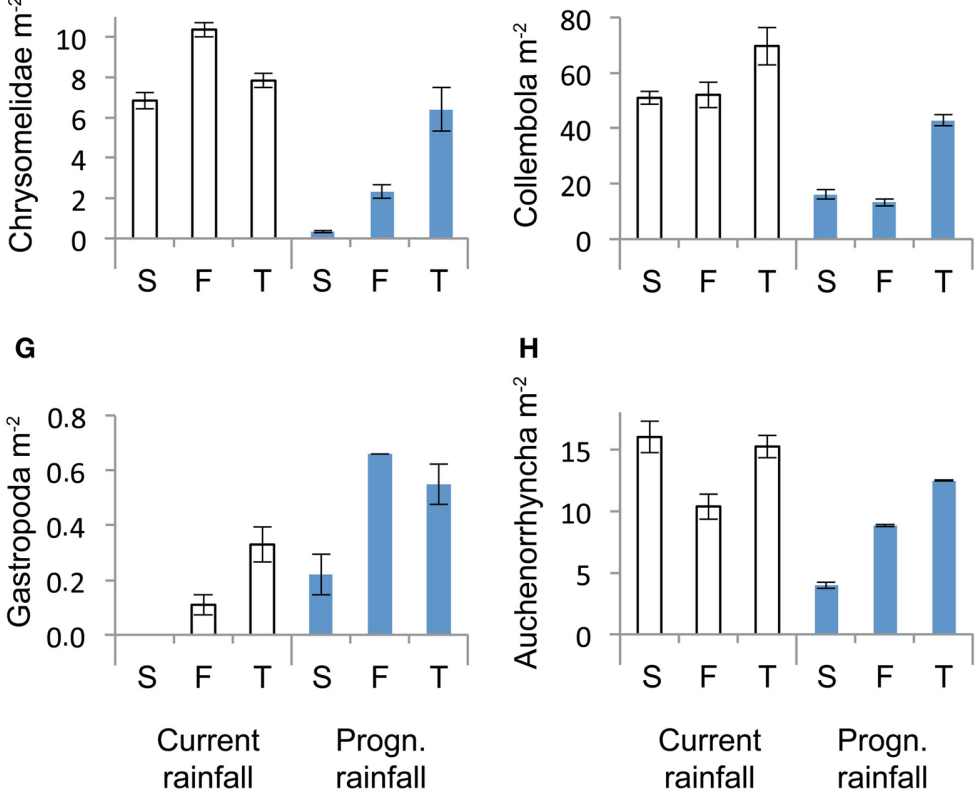

C

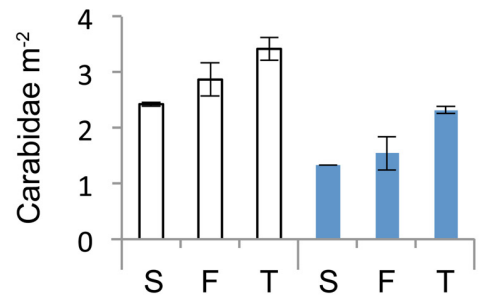

$\mathbf{F}$

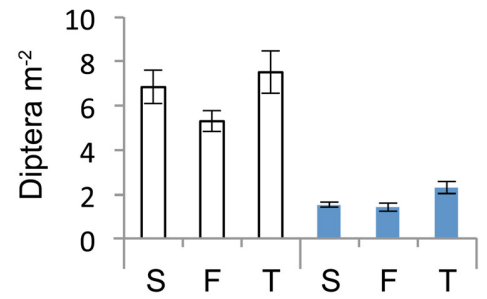

I

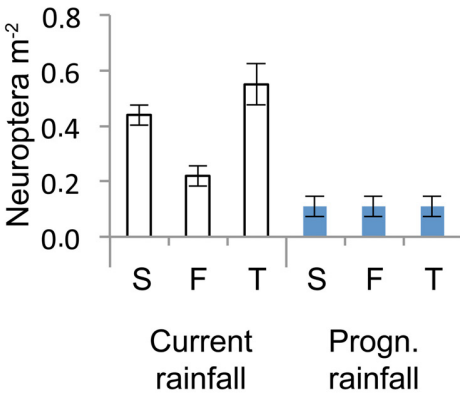

FIGURE 6 | Abundance of Araneae (A), Coleoptera (B), Carabidea (C), Chrysomelidae (D), Collembola (E), Diptera (F), Gastropoda (G), Auchenorrhyncha $(\mathrm{H})$ and Neuroptera $(\mathrm{I})$ in winter wheat across the three sampling dates (April, May, June) under current and predicted rainfall at the soil types calcaric phaeozem (S), gleyic phaeozem (F) and calcic chernozem (T). Means $\pm S E, n=3$.
Despite the small differences in rainfall it was interesting to see significant differences in abundances of Gastropoda and Auchenorrhyncha in April. However, given the small abundances of these taxa $\left(0.31 \mathrm{~m}^{-2}\right.$ for Gastropoda and $0.46 \mathrm{~m}^{-2}$ for Auchenorrhyncha) results should be interpreted with caution. On the other hand, the predicted rainfall plots received more precipitation than the current plots until April and Gastropoda are known to be very sensitive to rainfall (Choi et al., 2004) and might thus be sensitive indicators for changes in moisture. In our experiment Auchenorrhyncha (e.g., cicadas) also seemed to be sensitive to rainfall, although others found no differences in the abundance in summer drought plots compared to plots under ambient climate condition (Masters et al., 1998). Collembola, Diptera, Neuroptera, and Saltatoria responded to rainfall scenarios in May. This can be explained by a higher sensitivity to changes of these four orders, so that small differences in rainfall amounts $(9.8 \mathrm{~mm})$ and variation were effective, whereas the other orders appear to be more tolerant against changes in rainfall. Others also found that mites were not responsive to precipitation treatments, but Collembola were (Kardol et al., 2011).
In June 11 of the 18 arthropod groups investigated were affected by rainfall treatments suggesting that $20 \mathrm{~mm}$ difference in the amount of rainfall and $25 \%$ more dry days were enough for these taxa to respond. Finding that certain arthropod taxa were affected by rainfall treatments in 1 month but not in the other (e.g., Gastropoda, Saltatoria) can be explained by spatial and temporal variations of arthropod distribution between agroecosystems and the surrounding landscape (Afonina et al., 2001; Tscharntke et al., 2002; Zaller et al., 2008b). Clearly, to better understand the mechanisms underlying the relationship between rainfall amounts/variations and arthropod abundances an analysis at the species level would be desirable. However, it can be concluded from the current study that changes in rainfall variations with a slightly decreased amount of rainfall, more dry days and more intensive rainfall events will most likely decrease the abundance of aboveground arthropods in winter wheat crops.

Vegetation structural complexity, including crop biomass and weed abundance which differed between the rainfall treatments, is an important determinant of arthropod abundance and diversity in agroecosystems (Honek, 1988; Lagerlöf and Wallin, 1993; 


\begin{abstract}
Table 4 | Wheat height, wheat straw mass, weed abundance and biomass (all averaged across several sampling dates) in lysimeters cultivated with wheat in response to current vs. prognosticated rainfall variations and different soil types (S-calcaric phaeozem, F-gleyic phaeozem, T-calcic chernozem).
\end{abstract}

\begin{tabular}{|c|c|c|}
\hline Parameter/Soil type & Treatments Current Rainfall & Progn. Rainfall \\
\hline \multicolumn{3}{|l|}{ WHEAT HEIGHT (cm) } \\
\hline S soil & $42.8 \pm 0.7$ & $46.3 \pm 0.9$ \\
\hline F soil & $51.3 \pm 0.3$ & $48.9 \pm 2.5$ \\
\hline T soil & $48.7 \pm 0.7$ & $50.9 \pm 1.9$ \\
\hline \multicolumn{3}{|c|}{ ANOVA RESULTS FOR WHEAT HEIGHT } \\
\hline Rainfall & $P=0.121$ & \\
\hline Soil types & $P<0.001$ & \\
\hline Rainfall $\times$ Soil types & $P=0.009$ & \\
\hline \multicolumn{3}{|c|}{ WHEAT STRAW BIOMASS $\left(\mathrm{g} \mathrm{m}^{-2}\right)$} \\
\hline S soil & $49.2 \pm 1.1$ & $54.8 \pm 3.0$ \\
\hline F soil & $59.3 \pm 0.5$ & $57.2 \pm 3.6$ \\
\hline T soil & $55.8 \pm 1.1$ & $61.4 \pm 3.0$ \\
\hline \multicolumn{3}{|c|}{ ANOVA RESULTS FOR WHEAT STRAW BIOMASS } \\
\hline Rainfall & $P=0.018$ & \\
\hline Soil types & $P<0.001$ & \\
\hline Rainfall $\times$ Soil types & $P=0.021$ & \\
\hline \multicolumn{3}{|c|}{ WEED ABUNDANCE (ind. $\mathrm{m}^{-2}$ ) } \\
\hline S soil & $345.8 \pm 104.8$ & $239.6 \pm 68.1$ \\
\hline F soil & $118.1 \pm 48.9$ & $87.5 \pm 11.6$ \\
\hline T soil & $191.7 \pm 50.6$ & $156.9 \pm 40.7$ \\
\hline \multicolumn{3}{|c|}{ ANOVA RESULTS FOR WEED ABUNDANCE } \\
\hline Rainfall & $P=0.070$ & \\
\hline Soil types & $P<0.001$ & \\
\hline Rainfall $\times$ Soil types & $P=0.503$ & \\
\hline \multicolumn{3}{|c|}{ WEED BIOMASS $\left(\mathrm{g} \mathrm{m}^{-2}\right)$} \\
\hline S soil & $15.1 \pm 3.2$ & $18.9 \pm 2.8$ \\
\hline F soil & $8.5 \pm 5.8$ & $8.8 \pm 3.3$ \\
\hline T soil & $12.3 \pm 3.7$ & $9.6 \pm 3.7$ \\
\hline \multicolumn{3}{|c|}{ ANOVA RESULTS FOR WEED BIOMASS } \\
\hline Rainfall & $P=0.807$ & \\
\hline Soil types & $P=0.008$ & \\
\hline Rainfall $\times$ Soil types & $P=0.382$ & \\
\hline
\end{tabular}

Means $\pm S D$. Statistical results from Two-Way ANOVAs, significant effects are in bold.

Frank and Nentwig, 1995; Kromp, 1999). Correlations between arthropod abundance and crop and weed biomass suggest that the rainfall effects indirectly affect arthropods by changes on crops and weeds. Many studies describe the interrelation between weeds and arthropods, in which greater weed density and diversity is associated with higher numbers of arthropods (Moreby and Sotherton, 1997; Moreby and Southway, 1999; Marshall et al., 2003). In the current study, 45\% less weed biomass were found in the predicted rainfall plots than in current plots and thus the significant correlations for the abundance of arthropods (Acari, Araneae, Collembola, Diptera, and Thysanoptera) and weed biomass are not surprising. However, it is somewhat counterintuitive, that there was no correlation between numbers of individuals of weeds and abundance of arthropods, except
Table 5 | Correlation between arthropod abundance (June sampling) and straw and weed biomass (Pearson's product-moment correlation).

\begin{tabular}{lrrrrr}
\hline & \multicolumn{2}{c}{ Straw biomass } & & \multicolumn{2}{c}{ Weed biomass } \\
\cline { 2 - 3 } \cline { 5 - 6 } & \multicolumn{1}{c}{$\boldsymbol{R}$} & $\boldsymbol{P}$ & & $\boldsymbol{R}$ & $\boldsymbol{P}$ \\
\hline Acari & -0.292 & 0.240 & & 0.576 & $\mathbf{0 . 0 1 2}$ \\
Araneae & 0.120 & 0.635 & & 0.517 & $\mathbf{0 . 0 2 8}$ \\
Coleoptera & 0.338 & 0.170 & & 0.396 & 0.103 \\
Collembola & 0.168 & 0.505 & & 0.542 & $\mathbf{0 . 0 2 0}$ \\
Diptera & -0.002 & 0.995 & & 0.687 & $\mathbf{0 . 0 0 2}$ \\
Hemiptera & 0.048 & 0.849 & & 0.360 & 0.143 \\
Hymenoptera & -0.181 & 0.471 & & -0.355 & 0.148 \\
Not determinable & -0.013 & 0.960 & & 0.607 & $\mathbf{0 . 0 0 8}$ \\
Rare individuals & 0.381 & 0.119 & & 0.340 & 0.167 \\
Saltatoria & -0.226 & 0.368 & & 0.091 & 0.720 \\
Thysanoptera & 0.135 & 0.593 & & 0.745 & $<\mathbf{0 . 0 0 1}$ \\
Total individuals & 0.029 & 0.908 & & 0.451 & 0.060 \\
\hline
\end{tabular}

Significant correlations in bold.

for Hemiptera and total individuals in May. Also in contrast to other studies is the lack of a correlation between arthropod abundance and crop height (Frampton et al., 2000; Perner et al., 2005) indicating that our treatment factors rainfall and soil types influenced relationships between arthropods and plants. For example, the observed increased soil matric potential under progn. rainfall suggests that crop and weed plants in these treatments had soil water less easily available than plants in curr. rainfall treatments which could have affected the nutritional quality and structure of the crop-weed communities for arthropods (Masters et al., 1998). Plant responses to soil water availability can influence herbivore population dynamics with implications for multitrophic arthropod-plant interactions (Masters et al., 1993; Gange and Brown, 1997). Plant-mediated indirect effects of rainfall on arthropods have been described in detail for aphids where the performance of aphids on drought-stressed relative to healthy plants was increased, decreased or unchanged depending on the aphid species, host-plant, timing and severity of the drought stress (Pons and Tatchell, 1995). Whatever the causal mechanisms are, the decrease in arthropod abundance can have potential consequences for ecosystem function such as biological control, nutrient cycling, pollination, seed dispersal, plant decomposition, and soil alteration (Price, 1997; Bokhorst et al., 2008; Brantley and Ford, 2012). Arthropods control populations of other organisms and provide a major food source for other taxa, like birds or amphibia. Many farmland bird species are declining in Europe, and one reason could be a decreasing availability of arthropods (Moreby and Southway, 1999; Wilson et al., 1999; Hallmann et al., 2014). Insects are also an important supplementary human food source in many regions of the world, but as arthropods can also cause damage through feeding injury or transmission of plant-diseases, natural biological control in form of antagonistic arthropods are crucial for agricultural systems worldwide (Foottit and Adler, 2009). Our study also indicates that prognosticated rainfall variations might have little influence on biological control 
within the wheat agroecosystem as both important antagonists for pests (Araneae, Carabidae) and pests themselves (Chrysomelidae, Auchenorrhyncha) are reduced. However, the influence of rainfall on these pest-antagonist interactions demand more detailed investigations.

When interpreting our data one has to keep in mind that in climate change models temperature and precipitation are closely linked. Since we only investigated rainfall effects while leaving temperature unchanged, different impacts that the ones reported here could occur when both factors, temperature and precipitation, are studied simultaneously.

\section{ARTHROPOD ABUNDANCE LITTLE INFLUENCED BY SOIL TYPES}

Unlike expected, the soil types had no effect on arthropod abundances despite of clear differences in the availability of soil water as measured by the soil matric potential. Surprisingly, also orders which live in soil for most of its life cycle such as Collembola did not respond to soil types and the availability of soil water indicating that these taxa are rather tolerant to environmental conditions. As the factor soil type was rarely considered in studies on arthropods there is little literature to compare with. Differences in soil matric potential could also influence communities of soil bacteria and fungi and indirectly affect mycophagous and detritivorous arthropod species; however this remains to be investigated. Our current results of little influence of soil types on arthropods are in contrast with those who found significant differences in the abundance of spiders, carabides and Heteroptera in three different types of Estonian cultivated field soils; but there was also no difference between soil types regarding the number of Coleoptera (Ivask et al., 2008). When comparing those data one has to keep in mind that in the former study pitfall traps were used as opposed to suction sampling in the current study; moreover different times of the year in very different climatic regions were studied. In our study soil types influenced wheat height and weed abundance and the finding that some arthropod taxa were correlated with vegetation density suggests some relationship (Chapman et al., 1999). However, other factors, including competition between arthropod taxa from different trophic levels (Perner et al., 2005) might have overruled possible effects of soil types. In order to interpret these data in more detail, further studies investigating interactions between crop species and soil types would be necessary.

\section{CONCLUSION}

Taken together, this study suggests that future rainfall variations with less rainfall and longer drought periods during the vegetation period will significantly reduce the abundance of aboveground arthropods in winter wheat fields. The lack of significant effects of soil types suggests that rainfall variations most likely will have similar effects on different soil types. Weeds associated with winter wheat were shown to play an important role in promoting arthropod abundance while effects of rainfall on crop growth seemed to be of minor importance. The strong response of arthropod abundances to only small differences in rainfall amounts demands more appreciation of the effects of rainfall variations when studying climate change effects on ecological interactions in agroecosystems. As this is among the first studies investigating the combined effects of rainfall variations and soil types on the abundance of aboveground arthropods, more research is needed to get a better understanding of their consequences on ecosystem functioning and services.

\section{AUTHOR CONTRIBUTIONS}

Laura Simmer, James Tabi Tataw, Johannes Hösch, Erwin Murer, Johann G. Zaller conducted field work; Laura Simmer, Johann G. Zaller, Nadja Santer, Erwin Murer analyzed the data; Johann G. Zaller, Andreas Baumgarten, Herbert Formayer, Johannes Hösch, Johann G. Zaller conceived and designed the experiment; all authors wrote on the manuscript.

\section{ACKNOWLEDGMENTS}

We are grateful to Helene Berthold for providing logistical support during this project. Thanks to Karl Moder for statistical advice. This research was funded by the Austrian Climate and Energy Fund as part of the program ACRP2.

\section{REFERENCES}

Abbas, M. J., and Parwez, H. (2012). Impact of edaphic factors on the diversity of soil microarthropods in an agricultural ecosystem at Aligarh. Indian J. Fundam. Appl. Life Sci. 2, 185-191.

Afonina, V. M., Tshernyshev, W. B., Soboleva-Dokuchaeva, I. I., Timokhov, A. V., Timokhova, O. V., and Seifulina, R. R. (2001). Arthropod complex of winter wheat crops and its seasonal dynamics. IOBC Wprs Bull. 24, 153-164.

Alexandrov, V., Eitzinger, J., Cajic, V., and Oberforster, M. (2002). Potential impact of climate change on selected agricultural crops in north-eastern Austria. Glob. Change Biol. 8, 372-389. doi: 10.1046/j.1354-1013.2002.00484.x

Altieri, M. A. (1999). The ecological role of biodiversity in agroecosystems. Agric. Ecosyst. Environ. 74, 19-31. doi: 10.1016/S0167-8809(99)00028-6

Andow, D. A. (1991). Vegetational diversity and arthropod population response. Annu. Rev. Entomol. 36, 561-586. doi: 10.1146/annurev.en.36.010191.003021

Andrew, N. R., and Hughes, L. (2004). Species diversity and structure of phytophagous beetle assemblages along a latitudinal gradient: predicting the potential impacts of climate change. Ecol. Entomol. 29, 527-542. doi: 10.1111/j.03076946.2004.00639.x

Bährmann, R., and Müller, H. J. (2005). Bestimmung Wirbelloser Tiere. Heidelberg: Spektrum Akademischer Verlag.

Balmer, O., Pfiffner, L., Schied, J., Willareth, M., Leimgruber, A., Luka, H., et al. (2013). Noncrop flowering plants restore top-down herbivore control in agricultural fields. Ecol. Evol. 3, 2634-2646. doi: 10.1002/ece3.658

Batary, P., Holzschuh, A., Orci, K. M., Samu, F., and Tscharntke, T. (2012). Responses of plant, insect and spider biodiversity to local and landscape scale management intensity in cereal crops and grasslands. Agric. Ecosyst. Environ. 146, 130-136. doi: 10.1016/j.agee.2011.10.018

Beier, C., Beierkuhnlein, C., Wohlgemuth, T., Penuelas, J., Emmett, B., Körner, C., et al. (2012). Precipitation manipulation experiments-challenges and recommendations for the future. Ecol. Lett. 15, 899-911. doi: 10.1111/j.14610248.2012.01793.x

Bellmann, H. (1999). Der Neue Kosmos-Insektenführer. Stuttgart: Franckh-Kosmos. Bokhorst, S., Huiskes, A., Convey, P., Van Bodegom, P., and Aerts, R. (2008). Climate change effects on soil arthropod communities from the Falkland Islands and the Maritime Antarctic. Soil Biol. Biochem. 40, 1547-1556. doi: 10.1016/j.soilbio.2008.01.017

Brantley, S. L., and Ford, P. L. (2012). "Climate change and arthropods: pollinators, herbivores, and others," in Climate Change in Grasslands, Shrublands, and Deserts of the Interior American West: a Review and Needs Assessment, ed D. M. Finch (Fort Collins, CO: US Department of Agriculture, Forest Service, Rocky Mountain Research Station), 35-47.

Brook, A., Woodcock, B., Sinka, M., and Vanbergen, A. (2008). Experimental verification of suction sampler capture efficiency in grasslands of differing vegetation height and structure. J. Appl. Ecol. 45, 1357-1363. doi: 10.1111/j.13652664.2008.01530.x 
Buchholz, S. (2010). Simulated climate change in dry habitats: do spiders respond to experimental small-scale drought? J. Arachnol. 38, 280-284. doi: 10.1636/P09-91.1

Cannon, R. J. C. (1998). The implications of predicted cli- mate change for insect pests in the UK, with emphasis on non-indigenous species. Glob. Change Biol. 4, 785-796. doi: 10.1046/j.1365-2486.1998.00190.x

Chapman, P. A., Armstrong, G., and Mckinlay, R. G. (1999). Daily movements of Pterostichus melanarius between areas of contrasting vegetation density within crops. Entomol. Exp. Appl. 91, 477-480. doi: 10.1046/j.1570-7458.1999. 00516.x

Choi, Y., Bohan, D., Powers, S., Wiltshire, C., Glen, D., and Semenov, M. (2004). Modelling Deroceras reticulatum (Gastropoda) population dynamics based on daily temperature and rainfall. Agric. Ecosyst. Environ. 103, 519-525. doi: 10.1016/j.agee.2003.11.012

Christensen, J. H., and Christensen, O. B. (2007). A summary of the PRUDENCE model projections of changes in European climate by the end of this century. Clim. Change 81, 7-30. doi: 10.1007/s10584-006-9210-7

Coudrain, V., Schüepp, C., Herzog, F., Albrecht, M., and Entling, M. (2014). Habitat amount modulates the effect of patch isolation on host-parasitoid interactions. Front. Environ. Sci. 2:27. doi: 10.3389/fenvs.2014.00027

Curry, J. P. (1994). Grassland Invertebrates: Ecology, Influence on Soil Fertility and Effects on Plant Growth. London: Chapman \& Hall.

Danneberg, O., Baumgarten, A., Murer, E., Krenn, A., and Gerzabek, M. H. (2001). Stofftransport im System Boden-Wasser-Pflanze: Lysimeterversuche (Exkursion P2). Mitt. Österr. Bodenkundlichen Ges. 63, 193-208.

Drapela, T., Moser, D., Zaller, J. G., and Frank, T. (2008). Spider assemblages in winter oilseed rape affected by landscape and site factors. Ecography 31, 254-262. doi: 10.1111/j.0906-7590.2008.5250.x

Duelli, P., and Obrist, M. K. (2003). Regional biodiversity in an agricultural landscape: the contribution of seminatural habitat islands. Basic Appl. Ecol. 4, 129-138. doi: 10.1078/1439-1791-00140

Eitzinger, J., Zalud, Z., Alexandrov, V., Van Diepen, C. A., Trnka, M., Dubrovsky, M., et al. (2001). A local simulation study on the impact of climate change on winter wheat production in north-eastern Austria. Bodenkultur 52, 279-292.

Elmes, G. W., and Free, A. (1994). Climate Change and Rare Species. London, UK: HMSO.

FAO. (2002). "FAO/UNESCO Digital Soil Map of the World and derived soil properties. Land and Water Digital Map Series \#1 rev. 1." (Rome, Italy: FAO).

Finch, O. D., Loffler, J., and Pape, R. (2008). Assessing the sensitivity of Melanoplus frigidus (Orthoptera: Acrididae) to different weather conditions: a modeling approach focussing on development times. Insect Sci. 15, 167-178. doi: 10.1111/j.1744-7917.2008.00198.x

Foottit, R. G., and Adler, P. H. (2009). Insect Biodiversity: Science and Society. Chichester: Wiley-Blackwell.

Formayer, H., and Kromp-Kolb, H. (2009). Hochwasser und Klimawandel. Auswirkungen des Klimawandels auf Hochwasserereignisse in Österreich (Endbericht WWF 2006). BOKU-Met Report 7. Wien.

Frampton, G. K., Van Den Brink, P. J., and Gould, P. J. (2000). Effects of spring drought and irrigation on farmland arthropods in southern Britain. J. Appl. Ecol. 37, 865-883. doi: 10.1046/j.1365-2664.2000.00541.x

Frank, T., Aeschbacher, S., and Zaller, J. G. (2012). Habitat age affects beetle diversity in wildflower areas. Agric. Ecosyst. Environ. 152, 21-26. doi: 10.1016/j.agee.2012.01.027

Frank, T., and Nentwig, W. (1995). Ground dwelling spiders (Araneae) in sown weed strips and adjacent fields. Acta Oecol. 16, 179-193.

Gange, A. C., and Brown, V. K. (1997). Multitrophic Interactions in Terrestrial Systems. Oxford, UK: Blackwell Science.

Hallmann, C. A., Foppen, R. P. B., van Turnhout, C. A. M., de Kroon, H., and Jongejans, E. (2014). Declines in insectivorous birds are associated with high neonicotinoid concentrations. Nature 511, 341-343. doi: 10.1038/nature13531

Hamilton, J., Zangerl, A. R., Berenbaum, M. R., Sparks, J. P., Elich, L., Eisenstein, A., et al. (2012). Elevated atmospheric $\mathrm{CO}_{2}$ alters the arthropod community in a forest understory. Acta Oecologica 43, 80-85. doi: 10.1016/j.actao.2012. 05.004

Hegland, S. J., Nielsen, A., Lázaro, A., Bjerknes, A.-L., and Totland, O. (2009). How does climate warming affect plant-pollinator interactions? Ecol. Lett. 12, 184-195. doi: 10.1111/j.1461-0248.2008.01269.x
Hoffmann, H., and Rath, T. (2012). Meteorologically consistent bias correction of climate time series for agricultural models. Theor. Appl. Climatol. 110, 129-141. doi: 10.1007/s00704-012-0618-x

Hoffmann, H., and Rath, T. (2013). Future bloom and blossom frost risk for Malus domestica considering climate model and impact model uncertainties. PLoS ONE 8:e75033. doi: 10.1371/journal.pone.0075033

Honek, A. (1988). The effect crop density and microclimate on pitfall trap catches of Carabidae, Staphylinidae (Coleoptera) and Lycosidae (Araneae) in cereal fields. Pedobiologia 32, 233-242.

IPCC. (2007). Climate Change 2007: The Physical Science Basis. Fourth Assessment Report of the Intergovernmental Panel on Climate Change. Cambridge: Cambridge University Press.

IPCC. (2013). Climate Change 2013: The Physical Science Basis. Contribution to the Fifth Assessment Report of the Intergovernmental Panel on Climate Change (Cambridge: Cambridge University Press).

Ivask, M., Kuu, A., Meriste, M., Truu, J., Truu, M., and Vaater, V. (2008). Invertebrate communities (Annelida and epigeic fauna) in three types of Estonian cultivated soils. Eur. J. Soil Biol. 44, 532-540. doi: 10.1016/j.ejsobi.2008.09.005

Kardol, P., Reynolds, W. N., Norby, R. J., and Classen, A. T. (2011). Climate change effects on soil microarthropod abundance and community structure. Appl. Soil Ecol. 47, 37-44. doi: 10.1016/j.apsoil.2010.11.001

Kromp, B. (1999). Carabid beetles in sustainable agriculture: a review on pest control efficacy, cultivation impacts and enhancement. Agric. Ecosyst. Environ. 74, 187-228. doi: 10.1016/S0167-8809(99)00037-7

Kromp-Kolb, H., Formayer, H., Eitzinger, J., Thaler, S., Kubu, G., and Rischbeck, P. (2008). "Potentielle Auswirkungen und Anpassungsmaßnahmen der Landwirtschaft an den Klimawandel im Nordosten Osterreichs (WeinviertelMarchfeld Region)," in Auswirkungen des Klimawandels in Niederösterreich, ed H. Formayer (St. Pölten: Niederösterreichische Landesregierung), 96-140.

Lagerlöf, J., and Wallin, H. (1993). The abundance of arthropods along two field margins with different types of vegetation composition: an experimental study. Agric. Ecosyst. Environ. 43, 141-154. doi: 10.1016/0167-8809(93) 90116-7

Lensing, J. R., Todd, S., and Wise, D. H. (2005). The impact of altered precipitation on spatial stratification and activity-densities of springtails (Collembola) and spiders (Araneae). Ecol. Entomol. 30, 194-200. doi: 10.1111/j.03076946.2005.00669.x

Loranger-Merciris, G., Imbert, D., Bernhard-Reversat, F., Ponge, J.-F., and Lavelle, P. (2007). Soil fauna abundance and diversity in a secondary semi-evergreen forest in Guadeloupe (Lesser Antilles): influence of soil type and dominant tree species. Biol. Fertil. Soils 44, 269-276. doi: 10.1007/s00374-007-0199-5

Marshall, E. J. P., Brown, V. K., Boatman, N. D., Lutman, P. J. W., Squire, G. R., and Ward, L. K. (2003). The role of weeds in supporting biological diversity within crop fields. Weed Res. 43, 77-89. doi: 10.1046/j.1365-3180.2003.00326.x

Masters, G., Brown, V., Clarke, I., Whittaker, J., and Hollier, J. (1998). Direct and indirect effects of climate change on insect herbivores: auchenorrhyncha (Homoptera). Ecol. Entomol. 23, 45-52. doi: 10.1046/j.1365-2311.1998.00109.x

Masters, G. J., Brown, V. K., and Gange, A. C. (1993). Plant mediated interactions between above- and below-ground insect herbivores. Oikos 66, 148-151. doi: $10.2307 / 3545209$

Menalled, F. D., Smith, R. G., Dauer, J. T., and Fox, T. B. (2007). Impact of agricultural management on carabid communities and weed seed predation. Agric. Ecosyst. Environ. 118, 49-54. doi: 10.1016/j.agee.2006.04.011

Moreby, S., and Sotherton, N. (1997). A comparison of some important chick-food insect groups found in organic and conventionally-grown winter wheat fields in southern England. Biol. Agric. Horticult. 15, 51-60. doi: 10.1080/01448765.1997.9755181

Moreby, S., and Southway, S. (1999). Influence of autumn applied herbicides on summer and autumn food available to birds in winter wheat fields in southern England. Agric. Ecosyst. Environ. 72, 285-297. doi: 10.1016/S01678809(99)00007-9

Nestroy, O., Aust, G., Blum, W. E. H., Englisch, M., Hager, H., Herzberger, E., et al. (2011). Systematische Gliederung der Böden Österreichs. Österreichische Bodensystematik 2000 in der revidierten Fassung von 2011. Wien: Österreichische Bodenkundliche Gesellschaft.

Östman, Ö., Ekbom, B., Bengtsson, J., and Weibull, A.-C. (2001). Landscape complexity and farming practice influence the condition 
of polyphagous carabid beetles. Ecol. Appl. 11, 480-488. doi: 10.1890/1051-0761(2001)011[0480:LCAFPI]2.0.CO;2

Perner, J., Wytrykush, C., Kahmen, A., Buchmann, N., Egerer, I., Creutzburg, S., et al. (2005). Effects of plant diversity, plant productivity and habitat parameters on arthropod abundance in montane European grasslands. Ecography 28, 429-442. doi: 10.1111/j.0906-7590.2005.04119.x

Pfiffner, L., and Luka, H. (2003). Effects of low-input farming systems on carabids and epigeal spiders-a paired farm approach. Basic Appl. Ecol. 4, 117-127. doi: 10.1078/1439-1791-00121

Pons, X., and Tatchell, G. M. (1995). Drought stress and cereal aphid performance. Ann. Appl. Biol. 126, 19-31. doi: 10.1111/j.1744-7348.1995.tb05000.x

Porter, J. R., and Semenov, M. A. (2005). Crop responses to climatic variation. Philos. Trans. R. Soc. B Biol. Sci. 360, 2021-2035. doi: 10.1098/rstb.2005.1752

Price, P. W. (1997). Insect Ecology. New York, NY: John Wiley \& Sons.

Price, P. W., Denno, R. F., Eubanks, M. D., Finke, D. L., and Kaplan, I. (2011). Insect Ecology: Behavior, Populations and Communities. Cambridge: Cambridge University Press.

Querner, P., Bruckner, A., Drapela, T., Moser, D., Zaller, J. G., and Frank, T. (2013). Landscape and site effects on Collembola diversity and abundance in winter oilseed rape fields in eastern Austria. Agric. Ecosyst. Environ. 164, 145-154. doi: 10.1016/j.agee.2012.09.016

R Core Team. (2013). R: A Language and Environment for Statistical Computing. Vienna: R Foundation for Statistical Computing. Available online at: http:// www.R-project.org/

Reddersen, J. (1997). The arthropod fauna of organic versus conventional cereal fields in Denmark. Biol. Agricult. Horticul. 15, 61-71. doi: 10.1080/01448765.1997.9755182

Romanowsky, T., and Tobias, M. (1999). Vergleich der Aktivitätsdichten von Bodenarthropoden (insbesondere Laufkäfern, Carabidae) in zwei agrarisch geprägten Lebensräumen - Untersuchung zum Nahrungspotential einer Population der Knoblauchkröte (Pelobates fuscus Laurenti, 1768). Rana Sonderh. 3, 49-57.

Rosenzweig, M. L. (1995). Species Diversity in Space and Time. Cambridge: Cambridge University Press.

Seastedt, T. R., and Crossley, D. A. (1984). The influence of arthropods on ecosystems. BioScience 34, 157-161. doi: 10.2307/1309750

Semenov, M. A., and Barrow, E. M. (2002). "LARS-WG. A stochastic weather generator for use in climate impact studies," in User Manual (Harpenden: Rothamsted Research), 27.

Singer, M. C., and Parmesan, C. (2010). Phenological asynchrony between herbivorous insects and their hosts: signal of climate change or pre-existing adaptive strategy? Phil. Trans. R. Soc. B 365, 3161-3176. doi: 10.1098/rstb.2010.0144

Southwood, T. R. E. (1978). Ecological Methods. London: Methuen.

Speight, M. R., Hunter, M. D., and Watt, A. D. (2008). Ecology of Insects: Concepts and Applications. Oxford, UK: Wiley-Blackwell.

Steffan-Dewenter, I., Münzenberg, U., and Tscharntke, T. (2001). Pollination, seed set and seed predation on a landscape scale. Proc. R. Soc. Lond. B 268, 1685-1690. doi: 10.1098/rspb.2001.1737

Tabi Tataw, J., Hall, R., Ziss, E., Schwarz, T., Von Hohberg Und Buchwald, C., Formayer, H., et al. (2014). Soil types will alter the response of arable agroecosystems to future rainfall patterns. Ann. Appl. Biol. 164, 35-45. doi: 10.1111/aab.12072
Thaler, S., Eitzinger, J., Dubrovsky, M., and Trnka, M. (2008). "Climate change impacts on selected crops in Marchfeld, Eastern Austria. Paper 10.7," in 28th Conference on Agricultural and Forest Meteorology, 28 April - 2 May 2008, ed American Meteorological Society (Orlando).

Thies, C., Steffan-Dewenter, I., and Tscharntke, T. (2003). Effects of landscape context on herbivory and parasitism at different spatial scales. Oikos 101, 18-25. doi: 10.1034/j.1600-0706.2003.12567.x

Tscharntke, T., and Brandl, R. (2004). Plant-insect interactions in fragmented landscapes. Annu. Rev. Entomol. 49, 405-430. doi: 10.1146/annurev.ento.49.06 1802.123339

Tscharntke, T., Klein, A. M., Kruess, A., Steffan-Dewenter, I., and Thies, C. (2005). Landscape perspectives on agricultural intensification and biodiversityecosystem service management. Ecol. Lett. 8, 857-874. doi: 10.1111/j.14610248.2005.00782.x

Tscharntke, T., Steffan-Dewenter, I., Kruess, A., and Thies, C. (2002). Contribution of small habitat fragments to conservation of insect communities of grasslandcropland landscapes. Ecol. Appl. 12, 354-363. doi: 10.1890/1051-0761(2002)012 [0354:COSHFT $] 2.0 . \mathrm{CO} ; 2$

Wilson, J. D., Morris, A. J., Arroyo, B. E., Clark, S. C., and Bradbury, R. B. (1999). A review of the abundance and diversity of invertebrate and plant foods of granivorous birds in northern Europe in relation to agricultural change. Agric. Ecosyst. Environ. 75, 13-30. doi: 10.1016/S0167-8809(99) 00064-X

Zaller, J. G., Moser, D., Drapela, T., Schmoger, C., and Frank, T. (2008a). Insect pests in winter oilseed rape affected by field and landscape characteristics. Basic Appl. Ecol. 9, 682-690. doi: 10.1016/j.baae.2007.10.004

Zaller, J. G., Moser, D., Drapela, T., Schmöger, C., and Frank, T. (2008b). Effect of within-field and landscape factors on insect damage in winter oilseed rape. Agric. Ecosyst. Environ. 123, 233-238. doi: 10.1016/j.agee.2007. 07.002

Zaller, J., Moser, D., Drapela, T., and Frank, T. (2009). Ground-dwelling predators can affect within-field pest insect emergence in winter oilseed rape fields. Biocontrol 54, 247-253. doi: 10.1007/s10526-008-9167-8

Conflict of Interest Statement: The authors declare that the research was conducted in the absence of any commercial or financial relationships that could be construed as a potential conflict of interest.

Received: 28 May 2014; accepted: 01 October 2014; published online: 20 October 2014. Citation: Zaller JG, Simmer L, Santer N, Tabi Tataw J, Formayer H, Murer E, Hösch $J$ and Baumgarten A (2014) Future rainfall variations reduce abundances of aboveground arthropods in model agroecosystems with different soil types. Front. Environ. Sci. 2:44. doi: 10.3389/fenvs.2014.00044

This article was submitted to Agroecology and Land Use Systems, a section of the journal Frontiers in Environmental Science.

Copyright ๑ 2014 Zaller, Simmer, Santer, Tabi Tataw, Formayer, Murer, Hösch and Baumgarten. This is an open-access article distributed under the terms of the Creative Commons Attribution License (CC BY). The use, distribution or reproduction in other forums is permitted, provided the original author(s) or licensor are credited and that the original publication in this journal is cited, in accordance with accepted academic practice. No use, distribution or reproduction is permitted which does not comply with these terms. 